\title{
PENGARUH KOMISARIS INDEPENDEN, UKURAN PERUSAHAAN, DAN SALES GROWTH TERHADAP TAX AVOIDANCE PADA PERUSAHAAN TELEKOMUNIKASI YANG TERDAFTAR DI BURSA EFEK INDONESIA PERIODE 2016-2020
}

\author{
Feronika Rosalin ${ }^{1}$, Hasan Basri ${ }^{2}$ \\ Sekolah Tinggi Ilmu Ekonomi Mulia Darma Pratama \\ Email:, feronikarosalin@gmail.com¹, bhasan039@gmail.com²
}

\begin{abstract}
ABSTRAK
Penghindaran pajak (Tax Avoidance) adalah salah satu cara untuk menghindari pajak secara legal yang tidak melanggar peraturan perpajakan. Faktor-faktor yang memengaruhi penghindaran pajak antara lain return on asset, leverage, intensitas modal, pertumbuhan penjualan, komisaris independen dan ukuran perusahaan. Perumusan masalah dalam penelitian ini adalah (1) Bagaimana perkembangan komisaris independen, ukuran perusahaan, Sales Growth dan Tax Avoidance pada perusahaan telekomunikasi yang ada di Bursa Efek Indonesia periode 2016-2020? (2) Apakah komisaris independen, ukuran perusahaan, dan Sales Growth berpengaruh secara parsial terhadap Tax Avoidance pada perusahaan telekomunikasi yang ada di Bursa Efek Indonesia periode 2016-2020? (3) Apakah komisaris independen, ukuran perusahaan, dan Sales Growth berpengaruh secara simultan terhadap Tax Avoidance pada perusahaan telekomunikasi yang ada di Bursa Efek Indonesia periode 2016-2020?. Metode analisis yang digunakan adalah regresi linear berganda. Hasil penelitian secara parsial yaitu hasil uji t menunjukkan bahwa tidak terdapat pengaruh komisaris independen dan sales growth terhadap tax avoidane pada perusahaan telekomunikasi yang ada di Bursa Efek Indonesia periode 2016-2020, sedangkan ukuran perusahaan berpengaruh terhadap tax avoidance pada perusahaan telekomunikasi yang ada di Bursa Efek Indonesia periode 2016-2020. Sedangkan hasil penelitian secara simultan yaitu berdasarkan hasil uji $\mathrm{F}$ menunjukkan bahwa terdapat pengaruh komisaris independen, ukuran perusahaan, dan sales growth $(\mathrm{X} 1, \mathrm{X} 2, \mathrm{X} 3)$ secara simultan terhadap tax avoidance (Y) pada perusahaan telekomunikasi yang ada di Bursa Efek Indonesia periode 2016-2020. Nilai koefisien determinasi (Adjusted R square) adalah sebesar 0,276 atau 27,6\%. Hal ini menunjukkan bahwa pengaruh komisaris independen (X1), ukuran perusahaan (X2) dan sales growth (X3) terhadap tax avoidance (Y) sebesar 27,6\%, sisanya $72,4 \%$ dipengaruhi oleh variabel lain yang tidak dimasukkan dalam penelitian ini.

Kata Kunci : Komisaris Independen, Ukuran Perusahaan, Sales Growth, Tax Avoidance
\end{abstract}

ABSTRACT
Tax avoidance is one way to legally avoid taxes that does not violate tax regulations. Factors that
influence tax avoidance include non-asset returns, leverage, capital intensity, sales growth,
independent commissioners and company size. The formulation of the problem in this study is (1) How
is the development of independent commissioners, company size, Sales Growth and Tax Avoidance in
telecommunications companies listed on the Indonesia Stock Exchange for the 2016-2020 period? (2)
Do independent commissioners, company size, and Sales Growth have a partial effect on Tax Avoidance
in telecommunication companies listed on the Indonesia Stock Exchange for the 2016-2020 period? (3)
Do independent commissioners, company size, and Sales Growth have a simultaneous effect on Tax
Avoidance in telecommunication companies listed on the Indonesia Stock Exchange for the 2016-2020
period? The analytical method used is multiple linear regression. The results of the partial study,
namely the results of the t test, show that there is no influence of independent commissioners and sales
growth on tax avoidance in telecommunication companies listed on the Indonesia Stock Exchange for
the 2016-2020 period, while company size affects tax avoidance in telecommunication companies listed
on the Stock Exchange. Indonesia for the 2016-2020 period. While the results of simultaneous research
based on the results of the F test indicate that there is an effect of independent commissioners, company
size, and sales growth (X1, X2, X3) simultaneously on tax avoidance (Y) in telecommunications
companies listed on the Indonesia Stock Exchange for the 2016-2016 period. 2020. The value of the
coefficient of determination (Adjusted $R$ square) is 0.276 or 27.6\%. This shows that the influence of


independent commissioners (X1), company size (X2) and sales growth (X3) on tax avoidance $(Y)$ is $27.6 \%$, the remaining $72.4 \%$ is influenced by other variables not included in this study.

Keywords : Independent Commissioner, Company Size, Sales Growth, Tax Avoidance

\section{PENDAHULUAN}

Pajak merupakan sumber utama penerimaan negara, Pembayaran pajak merupakan perwujudan dari kewajiban kenegaraan dan peran serta Wajib Pajak untuk secara langsung dan bersama-sama melaksanakan kewajiban perpajakan untuk pembiayaan negara dan pembangunan nasional. Perusahaan sebagai salah satu wajib pajak memiliki kewajiban untuk membayar pajak sesuai dengan ketentuan perpajakan yang berlaku, yakni dihitung dari besarnya laba bersih sebelum pajak dikalikan dengan tarif pajak yang berlaku.

Penghindaran pajak (Tax Avoidance) adalah salah satu cara untuk menghindari pajak secara legal yang tidak melanggar peraturan perpajakan. Secara umum tindakan penghindaran pajak dianggap sebagai tindakan yang legal karena lebih banyak memanfaatkan loopholes yang ada dalam peraturan perpajakan yang berlaku (lawfull) (Santoso dan Ning, 2013:2).

\section{Penelitian Puspita dan Febrianti}

(2017) menyebutkan bahwa faktor-faktor yang memengaruhi penghindaran pajak antara lain return on asset, leverage, intensitas modal, pertumbuhan penjualan, komisaris independen, dimana hasil penelitiannya adalah ada pengaruh return on asset, leverage, intensitas modal, pertumbuhan penjualan, dan komisaris independen secara parsial maupun simultan terhadap penghindaran pajak. Daftar perusahaan jasa, sektor infrastruktur, utilitas dan transportasi, sub sektor telekomunikasi yang terdaftar sebagai perusahaan publik (emiten) di bursa efek Indonesia (BEI) terdapat 6 perusahan yaitu Bakrie Telecom,Tbk, Xl Axiata,Tbk, Smartren Telecom,Tbk, Indosat,Tbk, Jasnita Telekomindo,Tbk, dan Telekomunikasi Indonesia,Tbk (www.sahamok.net).

Penghindaran pajak atau Tax Avoidance dilakukan secara legal dengan cara mengurangi jumlah pajak terutang yang biasanya sering dilakukan oleh perusahaan. Berikut merupakan data beban pajak perusahaan telekomunikasi Indonesia yang terdaftar di BEI selama kurun waktu 5 tahun terakhir sebagai berikut:

\section{Tabel 1 \\ Daftar Beban Pajak \\ Perusahaan Telekomunikasi di BEI Periode 2016-2020 (Dalam Jutaan Rupiah)}

\begin{tabular}{|c|l|r|r|r|r|r|}
\hline No & \multicolumn{1}{|c|}{ Nama Perusahaan } & \multicolumn{1}{c|}{$\mathbf{2 0 1 6}$} & \multicolumn{1}{c|}{$\mathbf{2 0 1 7}$} & \multicolumn{1}{c|}{$\mathbf{2 0 1 8}$} & \multicolumn{1}{|c|}{$\mathbf{2 0 1 9}$} & \multicolumn{1}{c|}{$\mathbf{2 0 2 0}$} \\
\hline 1 & Bakrei Telkom, Tbk & 61.782 & 108.753 & 7.404 & 63 & 16 \\
\hline 2 & Xl Axiata, Tbk & 983 & 1.134 & 1.009 & 2.242 & 2.667 \\
\hline 3 & Smatfren Telcom,Tbk & 8.561 & 24.579 & 6.701 & 9.702 & 23.882 \\
\hline 4 & Janista Telekomindo,Tbk & 4.507 & 4.565 & 5.877 & 3.995 & 13.313 \\
\hline 5 & Telkom Indonesia,Tbk & 9.263 & 9.958 & 9.426 & 10.316 & 9.212 \\
\hline 6 & Indosat,Tbk & 142.483 & 638 & 356 & 49 & 30 \\
\hline
\end{tabular}

Sumber : www.idx.co.id (data diolah) 2021

Berdasarkan Tabel.1 Perusahaan Telkom Indonesia Tbk adalah perusahaan yang memiliki beban pajak sifatnya stabil per tiap tahunnya yaitu dapat dilihat pada tahun
2016 sebesar Rp. 9.263, pada tahun 2017 sebesar Rp. 9.958, pada tahun 2018 sebesar Rp 9.426, pada tahun 2019 sebesar Rp. 10.316, dan pada tahun 2020 sebesar Rp. 
9.212. Besarnya beban pajak berbanding lurus dengan laba/rugi yang dialami perusahaan. Berikut adalah Laporan
Laba/Rugi perusahaan telekomunikasi yang terdaftar di BEI selama 5 tahun terakhir.

Tabel 2

Daftar Laba/Rugi Sebelum Pajak

Perusahaan Telekomunikasi di BEI

Periode 2016-2020 (Dalam Jutaan Rupiah)

\begin{tabular}{|c|l|r|r|r|r|r|}
\hline No & \multicolumn{1}{|c|}{ Nama Perusahaan } & \multicolumn{1}{|c|}{$\mathbf{2 0 1 6}$} & \multicolumn{1}{|c|}{$\mathbf{2 0 1 7}$} & \multicolumn{1}{|c|}{$\mathbf{2 0 1 8}$} & \multicolumn{1}{c|}{$\mathbf{2 0 1 9}$} & \multicolumn{1}{c|}{$\mathbf{2 0 2 0}$} \\
\hline 1 & Bakrei Telkom, Tbk & $(1.330 .333)$ & $(1.605 .235)$ & $(727.979)$ & $(7.343)$ & $(108.121)$ \\
\hline 2 & Xl Axiata, Tbk & 3.449 & 4.469 & 4.396 & $(111.092)$ & $(182.557)$ \\
\hline 3 & Smatfren Telcom,Tbk & $(500.339)$ & $(245.092)$ & $(266.996)$ & $(151.445)$ & $(73.758)$ \\
\hline 4 & Janista Telekomindo,Tbk & $(38.563)$ & $(37.463)$ & $(38.956)$ & $(36.555)$ & $(28.809)$ \\
\hline 5 & Telkom Indonesia,Tbk & 37.457 & 42.659 & 36.405 & 37.908 & 38.775 \\
\hline 6 & Indosat,Tbk & $(531.745)$ & $(1.940)$ & $(1.430)$ & $(279)$ & $(559)$ \\
\hline
\end{tabular}

Sumber: www.idx.co.id (data diolah) 2021

Berdasarkan Tabel 2. dapat dilihat bahwa daftar laba/rugi masing-masing perusahaan telekomunikasi yang terdaftar di BEI periode 2016-2020 rata-rata mengalami kerugian, kecuali pada perusahaan Telkom Indonesia Tbk yaitu relatif stabil seperti pada tahun 2016 mengalami keuntungan sebesar Rp. 37.457, pada tahun 2017 sebesar Rp 42.659, pada tahun 2018 sebesar

Selain komisaris independen, ukuran perusahan juga berpengaruh terhadap Tax Avoidance, Ukuran perusahaan adalah suatu skala dimana besar kecilnya perusahaan dapat diklasifikasikan dalam berbagai cara, seperti log total aktiva, log total penjualan dan kapitalisasi pasar (Handayani dan Wulandari, 2014).

Selain ukuran perusahaan, pertumbuhan penjualan (Sales Growth) juga dapat mempengaruhi aktivitas Tax Avoidance. Laju pertumbuhan suatu perusahaan akan mempengaruhi kemampuan mempertahankan keuntungan dalam menandai kesempatan-kesempatan pada masa yang akan datang. Pertumbuhan penjualan tinggi, maka akan mencerminkan pendapatan meningkat sehingga pembayaran dividen cenderung meningkat. Pajak bagi perusahaan merupakan salah satu komponen biaya yang mengurangi laba perusahaan. Tidak sedikit wajib pajak terutama badan usaha yang melakukan penghindaran pajak
Rp. 36.405, pada tahun 2019 sebesar Rp. 37. 908, dan pada tahun 2020 sebesar Rp. 38.775 .

Karakteristik good corporate governance yang harus dimiliki perusahaan adalah komisaris independen, untuk mendukung pengelolaan perusahaan yang baik dan membuat laporan keuangan lebih objektif (Kurniasih dan Sari, 2013).

baik secara legal (Tax Avoidance) bahkan ilegal atau pengelapan pajak (Tax Evasion).

Objek penelitian yang dipilih ialah sektor telekomunikasi dikarenakan sektor ini adalah sektor yang terus berkembang pesat dari waktu ke waktu.

Berdasarkan fenomena kasus di atas, dapat dilihat bahwa adanya korelasi antara daftar beban pajak perusahaan dan daftar laba/rugi perusahaan pada perusahaan telekomunikasi yang terdaftar di BEI periode 2016 hingga 2020. Adanya perbedaan biaya pajak dan laba yang diterima perusahaan mengakibatkan perusahaan melakukan penghindaran pajak.

Dari latar belakang dan beberapa hasil penelitian sebelumnya, maka penulis tertarik untuk meneliti kembali dengan judul yaitu "Pengaruh Komisaris Independen, Ukuran Perusahaan, Dan Sales Growt Terhadap Tax Avoidance Pada Perusahaan Telekomunikasi Yang 
Terdaftar Di Bursa Efek Indonesia Periode 2016-2020".

\section{METODELOGI PENELITIAN}

\subsection{Tax Avoidance}

Penghindaran

pajak

(Tax

Avoidance) diartikan sebagai manipulasi penghasilan secara legal yang masih sesuai dengan ketentuan peraturan perundangundangan perpajakan untuk memperkecil jumlah pajak yang terutang.

\subsection{Komisaris Independen}

Komisaris Independen merupakan pihak yang ditunjuk tidak dalam kapasitas mewakili pihak mana pun dan semata-mata ditunjuk berdasarkan latar belakang pengetahuan, dan keahlian professional yang dimiliki untuk sepenuhnya menjalankan tugas demi kepentingan bersama.

\subsection{Ukuran Perusahaan}

Ukuran perusahaan adalah besar kecilnya perusahaan dapat diukur dengan total aktiva/besar harta perusahaan dengan menggunakan perhitungan nilai logaritma total aktiva.

\subsection{Sales Growth}

Sales Growth merupakan pertumbuhan penjualan yang mencerminkan keberhasilan investasi periode masa lalu dan dapat dijadikan sebagai prediksi pertumbuhan masa yang akan datang. Pertumbuhan penjualan merupakan indikator permintaan dan daya saing perusahaan dalam suatu industri.

\section{METODE PENELITIAN}

\subsection{Locus dan Objek Penelitian}

Locus pada penelitian ini adalah perusahaan telekomunikasi yang terdaftar di Bursa Efek Indonesia.

\subsection{Metode Penelitian}

Metode yang digunakan dalam penelitian ini adalah metode penelitian kuantitatif. Menurut Sugiyono (2014:55) penelitian kuantitatif adalah penelitian yang bertujuan untuk mengetahui hubungan dua variabel atau lebih. Adapun data yang digunakan dalam penelitian ini diperoleh dari (www.idx.co.id)

\subsection{Metode Analisis Data}

Metode analisis yang digunakan dalam penelitian ini adalah Analisis Deskriptif dan Verifikatif. Metode Deskriptif merupakan suatu metode penelitian yang menggambarkan karakteristik populasi atau fenomena yang sedang diteliti. Metode Verifikatif adalah metode penelitian melalui pembuktian untuk menguji hipotesis hasil penelitian deskriptif dengan perhitungan statistika sehingga didapat hasil pembuktian yang menunjukan hipotesis ditolak atau diterima (Sugiyono, 2014:13). Sebelum melakukan pengujian hipotesis, dilakukan uji asumsi klasik yaitu Uji Normalitas Data, Uji Multikolinieritas, Uji Heterokedastisitas, dan Autokorelasi.

\section{HASIL DAN PEMBAHASAN}

Tabel 3

\section{Hasil Analisis Regresi Linier Berganda}

Coefficients $^{\text {a }}$

\begin{tabular}{|c|c|c|c|c|c|c|c|}
\hline \multirow[b]{2}{*}{ Model } & \multicolumn{2}{|c|}{$\begin{array}{l}\text { Unstandardized } \\
\text { Coefficients }\end{array}$} & \multirow{2}{*}{$\begin{array}{c}\text { Standardized } \\
\text { Coefficients }\end{array}$} & \multirow[b]{2}{*}{$\mathrm{T}$} & \multirow[b]{2}{*}{ Sig. } & \multicolumn{2}{|c|}{$\begin{array}{c}\text { Collinearity } \\
\text { Statistics }\end{array}$} \\
\hline & $\mathrm{B}$ & Std. Error & & & & Tolerance & VIF \\
\hline 1 (Constant) & -16.889 & 5.070 & & -3.331 & .003 & & \\
\hline $\begin{array}{l}\text { Komisaris Independen } \\
\text { (X1) }\end{array}$ & 2.094 & 2.043 & .230 & 1.411 & .170 & .882 & 1.134 \\
\hline $\begin{array}{l}\text { Ukuran Perusahaan } \\
\text { (X2) }\end{array}$ & 13.594 & 3.049 & .605 & 3.532 & .002 & .729 & 1.372 \\
\hline Sales Growth (X3) & .004 & .424 & .002 & 0.010 & .992 & .787 & 1.271 \\
\hline
\end{tabular}


a.Dependent Variable: Tax Avoidance (Y)

Sumber: data diolah SPSS, 2021

Berdasarkan hasil output software SPSS pada Tabel 3 didapatkan persamaan regresi linier berganda sebagai berikut:

$$
\begin{aligned}
& Y= a+b_{1} \cdot X_{1}+b_{2} \cdot X_{2}+b_{3} \cdot X_{3}+e \\
& Y= \underset{ }{-16,889}+\mathbf{2 , 0 9 4} X_{1}+\mathbf{1 3 , 5 9 4} X_{2}+ \\
& \mathbf{0 , 0 0 4 X _ { 3 } + \mathbf { e }}
\end{aligned}
$$

$$
\begin{array}{ll}
\mathrm{Y} & =\text { Tax Avoidance } \\
\alpha & =\text { Koefisien Konstanta } \\
\mathrm{b}_{1}, \mathrm{~b}_{2}, & =\text { Koefisien regresi variabel } \\
\mathrm{b}_{3} & \text { independen } \\
\mathrm{X}_{1} & =\text { Komisaris Independen } \\
\mathrm{X}_{2} & =\text { Ukuran Perusahaan } \\
\mathrm{X}_{3} & =\text { Sales Growth } \\
\mathrm{e} & =\text { Faktor } \text { error }
\end{array}
$$

\begin{tabular}{|c|c|c|c|c|c|c|c|c|}
\hline \multirow{2}{*}{\multicolumn{2}{|c|}{ Model }} & \multicolumn{2}{|c|}{$\begin{array}{l}\text { Unstandardized } \\
\text { Coefficients }\end{array}$} & \multirow{2}{*}{$\begin{array}{c}\text { Standardized } \\
\text { Coefficients } \\
\text { Beta } \\
\end{array}$} & \multirow[b]{2}{*}{$\mathrm{T}$} & \multirow[b]{2}{*}{ Sig. } & \multicolumn{2}{|c|}{$\begin{array}{l}\text { Collinearity } \\
\text { Statistics }\end{array}$} \\
\hline & & B & Std. Error & & & & Tolerance & VIF \\
\hline \multirow[t]{4}{*}{1} & (Constant) & -16.889 & 5.070 & & -3.331 & .003 & & \\
\hline & Komisaris Independen (X1) & 2.094 & 2.043 & .230 & 1.411 & .170 & .882 & 1.134 \\
\hline & Ukuran Perusahaan (X2) & 13.594 & 3.049 & .605 & 3.532 & .002 & .729 & 1.372 \\
\hline & Sales Gro & . 004 & 424 & .002 & 0.010 & .992 & .787 & 1.271 \\
\hline
\end{tabular}

Keterangan:

Tabel 4

Hasil Uji Parsial (Uji t)

Coefficients $^{\mathrm{a}}$

a. Dependent Variable: Tax Avoidance (Y)

Sumber: data diolah SPSS, 2021

Berdasarkan hasil output SPSS didapatkan nilai thitung masing-masing variable dan ttabel yang dapat dilihat pada tabel statistik dengan signifikansi 0,05/2= 0,025 (uji dua sisi) dengan derajat kebebasan $\mathrm{df}=\mathrm{n}-\mathrm{k}-1$ atau $30-3-1=$ 26.

\section{Pengujian Komisaris Independen Terhadap Tax Avoidance}

Berdasarkan dari output SPSS didapatkan nilai thitung sebesar 1,411 berada di daerah penerimaan $\mathrm{H} 0$ atau 1,411 $<2,056$ dan signifikansi $>0,05$ atau 0,170 $>0,05$, karena masuk dalam daerah penerimaan, maka $\mathrm{HO}$ diterima atau menolak Ha. Hal ini menunjukkan bahwa komisaris independen tidak berpengaruh terhadap tax avoidance.

\section{Pengujian Ukuran Perusahaan Terhadap Tax Avoidance}

Berdasarkan dari output SPSS didapatkan nilai thitung sebesar 3,532 berada di daerah penolakan $\mathrm{H} 0$ atau 3,532 $>$ 2,056 dan signifikansi $<0,05$ atau 0,002 $<0,05$, karena masuk dalam daerah penolakan H0, maka $\mathrm{HO}$ ditolak atau menerima Ha. Hal ini menunjukkan bahwa ukuran perusahaan berpengaruh terhadap tax avoidance.

\section{Pengujian Sales Growth Terhadap Tax Avoidance}

Berdasarkan dari output SPSS didapatkan nilai thitung sebesar 0,010 berada di daerah penerimaan $\mathrm{H} 0$ atau 0,010 $<2,056$ dan signifikansi $>0,05$ atau 0,992 $>0,05$, karena masuk dalam daerah penerimaan $\mathrm{H} 0$, maka $\mathrm{H} 0$ diterima atau menolak Ha. Hal ini menunjukkan bahwa sales growth tidak berpengaruh terhadap tax avoidance. 
Hasil Uji Simultan (Uji F)

ANOVA ${ }^{b}$

\begin{tabular}{|c|c|c|c|c|c|c|}
\hline \multicolumn{2}{|c|}{ Model } & Sum of Squares & $\mathrm{df}$ & Mean Square & $\mathrm{F}$ & \multirow{4}{*}{$\begin{array}{l}\text { Sig. } \\
\quad .010^{\mathrm{a}}\end{array}$} \\
\hline 1 & Regression & .394 & 3 & \multirow{3}{*}{$\begin{array}{l}.098 \\
.071\end{array}$} & \multirow[t]{3}{*}{4.682} & \\
\hline & Residual & .545 & 26 & & & \\
\hline & Total & .836 & 29 & & & \\
\hline
\end{tabular}

a. Predictors: (Constant), Sales Growth (X3), Komisaris Independen (X1), Ukuran Perusahaan (X2)

b. Dependent Variable: Tax Avoidance (Y)

Sumber: data diolah SPSS, 2021

Berdasarkan Tabel 5 diperoleh nilai Fhitung sebesar 4,682 dan Ftabel yang dapat dilihat pada tabel statistik dengan tingkat signifikansi 0,05 dengan df $1 \mathrm{n}=$ (jumlah variabel -1 ) atau $3-1=2, \mathrm{df} 2 \mathrm{n}=$ $(\mathrm{n}-\mathrm{k})$ atau 30-2 = 28, Ftabel adalah sebesar 3,34 dapat dilihat di tabel Ftabel, dengan demikian dapat disimpulkan bahwa Fhitung $>$ Ftabel atau 4,682 > 3,34 dengan tingkat signifikansi $<0,05$ atau $0,010<0,05$. Dengan demikian dapat disimpulkan bahwa
Fhitung > Ftabel atau 4,682 > 3,34 dengan tingkat signifikansi $<0,05$ atau $0,010<$ 0,05 . Hal ini menunjukkan bahwa minimal ada satu variabel $X$ yaitu komisaris independen, ukuran perusahaan, dan sales growth $(\mathrm{X} 1, \mathrm{X} 2, \mathrm{X} 3)$ berpengaruh terhadap tax avoidance (Y) pada perusahaan telekomunikasi yang ada di Bursa Efek Indonesia periode 2016-2020.

\section{Tabel 6}

Hasil Analisis Koefisien Determinasi $\left(\mathbf{R}^{2}\right)$ Model Summary ${ }^{b}$

\begin{tabular}{|l|r|r|r|r|r|}
\hline Model & \multirow{2}{*}{$\mathrm{R}$} & \multicolumn{1}{|c|}{$\mathrm{R}$ Square } & Adjusted R Square & $\begin{array}{c}\text { Std. Error of the } \\
\text { Estimate }\end{array}$ & \multicolumn{1}{c|}{ Durbin-Watson } \\
\cline { 4 - 7 } 1 & $.592^{\mathrm{a}}$ & .351 & .276 & .144720 & 1.173 \\
\hline
\end{tabular}

a. Predictors: (Constant), Sales Growth (X3), Komisaris Independen (X1), Ukuran Perusahaan (X2)

b. Dependent Variable: Tax Avoidance (Y)

Sumber: data diolah SPSS, 2021

Berdasarkan Tabel 6 dapat dilihat nilai koefisien determinasi (Adjusted $R$ square) adalah sebesar 0,276 atau 27,6\%. Dengan demikian, dapat diartikan pengaruh komisaris independen $\left(\mathrm{X}_{1}\right)$, ukuran perusahaan $\left(\mathrm{X}_{2}\right)$ dan sales growth $\left(\mathrm{X}_{3}\right)$ terhadap tax avoidance $(\mathrm{Y})$ sebesar $27,6 \%$, sisanya $72,4 \% \quad(100 \%-27,6 \%)$ dipengaruhi oleh variabel lain yang tidak dimasukkan dalam penelitian ini.

\section{KESIMPULAN DAN SARAN 5.1 Kesimpulan}

Berdasarkan hasil analisis dan pembahasan yang telah diuraikan pada bab sebelumnya mengenai pengaruh komisaris independen, ukuran perusahaan, dan sales growth (X1, X2, X3) terhadap tax avoidance (Y) pada perusahaan telekomunikasi yang ada di Bursa Efek Indonesia periode 2016-2020, maka penulis dapat menarik kesimpulan sebagai berikut:

1. Perkembangan komisaris independen pada perusahaan telekomunikasi di Bursa Efek Indonesia periode 20162020 yaitu relatif konstan, artinya selama kurun waktu penelitian (20162020) komposisi komisaris independen tidak mengalami penambahan atau 
pengurangan dalam komposisi dewan komisaris.

2. Perkembangan ukuran perusahaan pada perusahaan telekomunikasi di Bursa Efek Indonesia periode 20162020 untuk perusahaan Bakrie Telecom Tbk. cenderung mengalami penurunan, untuk perusahaan $\mathrm{Xl}$ Axiata Tbk. pada tahun 2016-2020 mengalami peningkatan, untuk perusahaan Smartren Telecom Tbk. pada tahun 2016-2020 mengalami peningkatan, untuk perusahaan Jasnita Telekomindo Tbk. pada tahun 20162020 mengalami peningkatan kecuali tahun 2020 mengalami penurunan dibandingkan tahun 2019, untuk perusahaan Indosat Tbk. pada tahun 2016-2020 mengalami fluktuasi, dan untuk perusahaan Telekomunikasi Indonesia Tbk pada tahun 2016-2020 mengalami peningkatan.

3. Perkembangan sales growth pada perusahaan telekomunikasi di Bursa Efek Indonesia periode 2016-2020 untuk perusahaan Bakrie Telecom Tbk., Xl Axiata Tbk., Smartren Telecom Tbk., Indosat Tbk., dan Jasnita Telekomindo mengalami fluktuasi. Sedangkan perkembangan Sales growth pada perusahaan Telekomunikasi Indonesia Tbk pada tahun 2016-2020 mengalami penurunan.

4. Perkembangan tax avoidance pada perusahaan telekomunikasi di Bursa Efek Indonesia periode 2016-2020 untuk Xl Axiata Tbk. pada tahun 20162020 mengalami penurunan. Sedangkan untuk Bakrie Telecom Tbk., Smartren Telecom Tbk., Indosat Tbk., Jasnita Telekomindo Tbk., dan Telekomunikasi Indonesia Tbk mengalami fluktuasi.

5. Hasil uji t menunjukkan bahwa tidak terdapat pengaruh komisaris independen dan sales growth terhadap tax avoidance pada perusahaan telekomunikasi yang ada di Bursa Efek Indonesia periode 2016-2020, sedangkan ukuran perusahaan berpengaruh terhadap tax avoidance pada perusahaan telekomunikasi yang ada di Bursa Efek Indonesia periode 2016-2020.

6. Berdasarkan hasil uji $\mathrm{F}$ menunjukkan bahwa terdapat pengaruh komisaris independen, ukuran perusahaan, dan sales growth (X1, X2, X3) secara simultan terhadap tax avoidance $(\mathrm{Y})$ pada perusahaan telekomunikasi yang ada di Bursa Efek Indonesia periode 2016-2020. Hal ini dibuktikan dengan nilai Fhitung $(4,682)>$ Ftabel $(3,34)$ dan nilai signifikansi $<0,05$ atau 0,010 $<0,05$.

7. Nilai koefisien determinasi (Adjusted $\mathrm{R}$ square) adalah sebesar 0,276 atau $27,6 \%$. Hal ini menunjukkan bahwa pengaruh komisaris independen (X1), ukuran perusahaan (X2) dan sales growth (X3) terhadap tax avoidance (Y) sebesar $27,6 \%$, sisanya $72,4 \%$ dipengaruhi oleh variabel lain yang tidak dimasukkan dalam penelitian ini.

\subsection{Saran}

Berdasarkan kesimpulan dari hasil penelitian, maka penulis memberikan saran-saran kepada pihak perusahaan, investor, dan penelitian selanjutnya sebagai berikut:

\section{Bagi Perusahaan}

Hasil penelitian ini dapat menjadikan perusahaan lebih berhati-hati dalam mengambil keputusan untuk melakukan tax avoidance (penghindaran pajak) dalam rangka keagresifan terhadap pajak walaupun tax avoidance (penghindaran pajak) bersifat legal. Selain itu penelitian ini juga dapat digunakan oleh perusahaan untuk menghindari sanski administrasi pajak akibat agresivitas pajak.

2. Bagi Investor 
Hasil penelitian ini dapat memberikan gambaran dan membantu investor dalam melakukan analisis laporan keuangan untuk memahami tax avoidance (penghindaran pajak) yang dilakukan perusahaan dengan tujuan agresivitas pajak.

\section{Bagi Peneliti Selanjutnya}

Peneliti selanjutnya diharapkan dapat mengganti objek penelitian pada emiten sektor lain yang ada di Bursa Efek Indonesia dan menambah variabel independen lainnya, sehingga bisa dilihat secara empiris tentang tax avoidance di perusahaan

\section{DAFTAR PUSTAKA}

Handayani, Desi dan Wulandari, Hesty. (2014). Pengaruh Kepemilikan Pemerintah dan Ukuran Perusahaan Terhadap Tarif Pajak EfektifPerusahaan. Jurnal Akuntansi Keuangan dan Bisnis. Vol. 7.

Kurniasih, Tommy dan Sari, Maria M Ratna. (2013). "PengaruhReturn on Asset, Leverage, Corporate Governance, Ukuran Perusahaan dan Kompensasi Rugi Fiskal pad aTax Avoidance". Buletin Studi Ekonomi ISSN 1410-4628, Volume 18 No. 1, Februari 2013.

Puspita, Deanna dan Febrianti, Meiriska. (2017). Faktor-Faktor yang Memengaruhi Penghindaran Pajak pada Perusahaan Manufaktur di Bursa Efek Indonesia. Jurnal Bisnis dan Akuntansi, Vol. 19, No. 1: 38-46.

Santoso, Iman dan Ning, Rahayu. (2013). Corporate Tax Management. Observation and Research of Taxation (Ortax). Jakarta.

Sugiyono. 2014. Metode Penelitian Bisnis (Pendekatan Kuantitatif, Kualitatif dan R\&D). Bandung: Alfabeta. www.idx.co.id (Diakses pada tanggal 19 Mei 2021). 